\title{
Larval habitat of Ochlerotatus albifasciatus (Diptera: Culicidae) in the southern edge of the Americas, Tierra del Fuego Island
}

\author{
Nora Edith Burroni ${ }^{1 *}$, María Verónica Loetti ${ }^{1}$, María Cristina Marinone $^{2,3}$, \\ María Gabriela Freire ${ }^{1}$, Nicolás Schweigmann ${ }^{1,4}$

\footnotetext{
${ }^{1}$ Mosquito Study Group, Department of Ecology, Genetics and Evolution, Institute IEGEBA (CONICET-UBA), Faculty of Exact and Natural Sciences, University of Buenos Aires, Buenos Aires, Argentina;

*Corresponding Author: nburroni@ege.fcen.uba.ar

${ }^{2}$ Arthropods Laboratory, Department of Biodiversity and Experimental Biology, Faculty of Exact and Natural Sciences, University of Buenos Aires, Buenos Aires, Argentina

${ }^{3}$ Institute of Biodiversity and Experimental and Applied Biology (IBBEA), UBA-CONICET, Buenos Aires, Argentina
} \\ ${ }^{4}$ National Council of Scientific and Technological Research (CONICET), Buenos Aires, Argentina
}

Received 6 September 2013; revised 29 September 2013; accepted 8 October 2013

Copyright (C) 2013 Nora Edith Burroni et al. This is an open access article distributed under the Creative Commons Attribution License, which permits unrestricted use, distribution, and reproduction in any medium, provided the original work is properly cited.

\section{ABSTRACT}

The information about ecological topics of mosquitoes at the southernmost tip of South America is fragmentary and scarce. The present study evaluates lentic freshwater habitat located in the surroundings of main roads of the Argentine sector of Tierra del Fuego as larval habitat of Ochlerotatus albifasciatus, also analyzes the relationships between their presence and several environmental variables: water turbidity, percentage of gramineans, percentage of macrophytes, presence of crustaceous cyanobacteria, and filamentous chlorophyceans. Mosquito inmatures were collected with dip nets. A generalized linear model (GLM) with negative binomial error distribution was used to determine the effects of different variables of the water bodies on abundance of Oc. albifasciatus in the larval habitats. Collections were made in 45 lentic freshwater bodies. Preimaginal stages were found in $17.70 \%$ of the studied habitats. Oc. albifasciatus was the only culicid registered. The GLM explained $93.17 \%$ of the variability, and showed a negative relationship between the abundances of Oc. albifasciatus and water turbidity, and a positive relationship with percentage of gramineans. The gramineans would improve food supply, because the plants are providing suitable substrate for different types of microbiota, a layer of leaves would protect eggs from extreme temperatures, and could help the larvae to hide from potential predators. The negative association between abundance of this species with water turbidity could be related to the presence of vegetation that favors retaining the substrate, reducing water turbidity.

Keywords: Ochlerotatus; Mosquitoes; Larval Habitat; Patagonia; South America

\section{INTRODUCTION}

Knowledge of the mosquito larval habitat and the habitat conditions favouring the presence of immature mosquitoes is essential to understanding the ecology of culicid populations, particularly for species acting as vectors of important human and animal diseases [1].

At the southernmost tip of South America, the information about ecological topics on mosquitoes is fragmentary and scarce. In Patagonia, Chubut Province $\left(45^{\circ} 35^{\prime} \mathrm{S}, 69^{\circ} 05^{\prime} \mathrm{W}\right)$, Burroni et al. [2] found Ochlerotatus albifasciatus and Culex eduardoi in a study on wetlands in agroecosystems (Burroni et al. [3]), and an update of the distribution of the species in Patagonia Argentina shows that its northern provinces registered between 6 and 14 species, whereas the southernmost continental province of Patagonia (Santa Cruz) has only 5 species [4]. In particular, in the Tierra del Fuego Island (Argentina), Bachmann and Bejarano [5] reported adults of Oc. albifasciatus (Macquart 1838) in Ushuaia City and Lapataia Bay documenting the irritating effects of their bites on humans due to the high abundance of 
mosquitoes at this high latitude. In addition, adults of this species were reported by Marinone [6] from Kosobo Lake, located $74 \mathrm{~km}$ to the northeast of Ushuaia. This persistent biter that causes considerable discomfort both to humans [7] and to cattle [8], has sanitary importance since it has been recognized as a competent vector of the western equine encephalitis virus [9-12]: the east equine encephalitis virus and the Valle Cache virus [13]; and of Dirofilaria immitis, the etiological agent of canine filariasis $[9,14]$.

Information about the larval habitat of culicids is not available for the Tierra del Fuego Island, and ref. [4] has recently pointed out the lack of information about bionomics of mosquitoes in this region. This study was aimed at evaluating lentic freshwater habitat located in the surroundings of the main roads of the Grand Island of Tierra del Fuego (Argentina) as potential larval habitat for Oc. albifasciatus, and analyzing the relationships between the abundance of their immature stages and several key environmental variables.

\section{MATERIALS AND METHODS}

\subsection{Study Area}

This study was carried out in the Grand Island of Tierra del Fuego (Argentine sector) $\left(52^{\circ} 33^{\prime}-55^{\circ} 00^{\prime} \mathrm{S}\right.$, $65^{\circ} 46^{\prime}-68^{\circ} 41^{\prime} \mathrm{W}$ ), from 8 to 14 January 2002 . The climate of this island is cold-temperate with a mean annual temperature between $4^{\circ} \mathrm{C}$ and $6^{\circ} \mathrm{C}[15]$ and a mean annual precipitation between 300 and $500 \mathrm{~mm}$. The island is characterized by little temperature fluctuations due to the maritime influence, precipitations all year round, high cloudiness, no frost-free period, and strong westerly and southwesterly winds [16].

Because of its severe weather and harsh relief, Tierra del Fuego has experienced a relatively low level of anthropogenic impact [17]. The $48,100 \mathrm{~km}^{2}$ of the island are populated by 126,190 inhabitants who settled there during the last decades (http://economia.tierradelfuego. gov.ar). The region corresponds to the Fueguinian District of the Patagonian phytogeographic Province belonging to the Neotropical Region [18]. Two distinct landscape areas can be distinguished in the island: 1) an open steppe with large plains, isolated hills and plateaus covered with gramineous plants to the north, and 2) woodlands to the south (Figure 1(a)). The northern steppe zone characterized by an annual mean temperature between $5^{\circ} \mathrm{C}$ and $6^{\circ} \mathrm{C}$, accumulated annual precipitations of $300-400 \mathrm{~mm}$, and persistent strong westerly winds The southern woodlands zone is partially sheltered from the winds by the presence of the southernmost continental heights of the Andes mountain range, having annual precipitations of $500 \mathrm{~mm}$ and annual mean temperatures of $4^{\circ} \mathrm{C}[19]$.

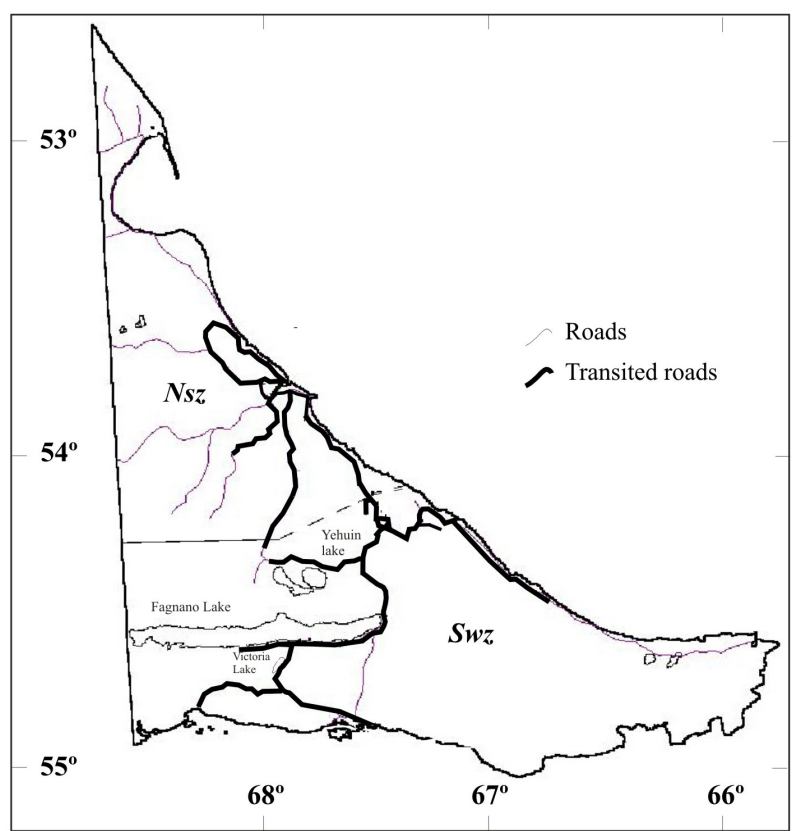

(a)

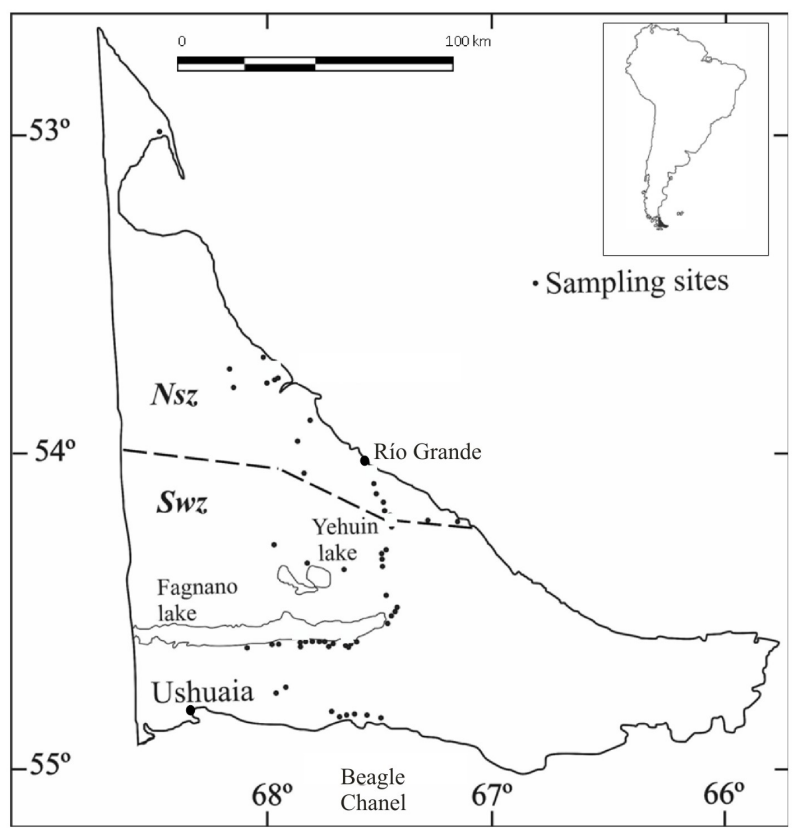

(b)

Figure 1. a) Main routes and roads in the argentine sector of Grand Island of Tierra del Fuego. Those that were transited in search of freshwater water bodies are indicated in thick line. The dashed line indicates the approximate limit between the northern steppe (Nsz) and the southern woodland (Swz) zones; b) Location of the freshwater water bodies surveyed of the Grand Island of Tierra del Fuego, on January 2002.

\subsection{Sample Collection}

About $1000 \mathrm{~km}$ of the main routes and roads of the island were traveled to sample lentic freshwater bodies located in their surroundings (Figure 1(a)). Mosquito 
inmatures were collected with $350 \mu$ m-mesh dip nets with square frames. The nets were swept sideways and turned back along the same path to collect dislodged organisms [20]. Three persons sampled for $20-30 \mathrm{~min}$ in the open water, littoral areas and along the bottom, in each water body $<1 \mathrm{~m}$ deep, and only in the littoral zone in wetlands $>1 \mathrm{~m}$ deep, so that the sample size was proportional to the surface area of each environment. The material was fixed in situ in $80 \%$ ethanol.

The following environmental variables were recorded at each habitat: a) water turbidity (on a scale from 0 (transparent) to 1 (very turbid) (estimated visually within a $20-\mathrm{cm}$ diameter by $15-\mathrm{cm}$ deep white container), b) percentage of gramineans, c) percentage of macrophytes, d) presence of macroscopic algae crustaceous cyanobacteria, and e) presence of filamentous chlorophyceans. The percentage of gramineans and macrophytes was computed with the cover abundance scale for vegetation of Braun-Blanquet [21].

Immature mosquitoes were identified to the species level [22]. Same larvae and pupae were reared to adult emergence to confirm the species collected. The abbreviation of mosquito genera follows Reinert [23]. The material is held in the larval collection of N. E. Burroni (Laboratory of Grupo de Estudio de Mosquitos, Buenos Aires University, Argentina).

\subsection{Data Analysis}

A generalized linear model (GLM) [24] analysis with negative binomial error distribution and log link function was used to determine the effects of different variables of the water bodies on abundance of Oc. albifasciatus in the larval habitats. Statistical analyses were carried out using R software, Version 2.15.1 (R Development Core Team 2011). The water turbidity, the percentage of gramineans and macrophytes were treated as quantitative variables, and the crustaceous cyanobacterias, filamentous chlorophyceans presence, were treated as factors.

\section{RESULTS}

Collections were made in 45 lentic freshwater water bodies (Figure 1(b)). Oc. albifasciatus was the only species of culicid registered. Preimaginal stages of this species were found in $17.7 \%$ of the habitats, but it was only found in one type of water body, the roadside pools. This water boy type was the more abundance (Table 1). The number of each type of environment sampled was approximately proportional to its relative abundance in the area.

A total of 365 inmatures were accounted, and all specimens of culicids were found in the southern woodland zone of the island.

The generalized linear model (GLM) performed between the abundance of Oc. albifasciatus and environmental variables of larval habitats explained $93.17 \%$ of the variability.

This analysis of GLM showed a negative relationship between the abundances of Oc. albifasciatus and water turbidity, and a positive relationship with percentage of gramineans (Table 2).

\section{DISCUSSION}

In agreement with former reports of adult culicids for Tierra de Fuego [5,6], the only species detected in our study was Oc. albifasciatus, which was widely distributed in southern South America. This species has been reported from southern Brazil, Bolivia, Paraguay, Uruguay, Chile, continental Argentina-excepting the arid Provinces of San Luis and San Juan-[25,26], and Tierra del Fuego, which is the southern limit of its distribution. So far, the works on the larval habitats of Oc. albifasciatus have been carried out in temperate zones [e.g. 27-30], therefore, this study represents the first one dealing with larval habitat characteristics of this species in the austral extreme of the Americas.

The insular condition of Tierra del Fuego with its very low temperatures year round and the pervasive strong

Table 1. Number, origin and presence of Oc. albifasciatus of water body type sampled in Argentine sector of Grand Island of Tierra del Fuego.

\begin{tabular}{cccc}
\hline Water body type & N & Origin of the water body & Made by road construction \\
Roadside pools & 24 & Dug to provide stone for road construction \\
Quarry pools & 3 & Caused by stream or river overflow \\
Floodplain pools & 6 & Located in Sphagnum sp. peatlands \\
Peatland ponds & 3 & Water body modeling by these animals \\
Beaver ponds & 4 & A \\
Large ponds & 5 & A
\end{tabular}

Presence $=\mathrm{P} ;$ Absence $=\mathrm{A}$. 
Table 2. Generalized linear model coefficients, standar error (SE) and $Z$ values of these coefficients performed to studied the effects of environmental variables of larval habitat on Oc. albifasciatus abundance. Theta: 1.054 (Std. Err $=0.574)$.

\begin{tabular}{|c|c|c|c|c|}
\hline Coefficients & Estimate & SE & $Z$ value & \\
\hline Intercept & -6.059 & 1.602 & -3.782 & ${ }^{* * *}$ \\
\hline Gramineans percentage & 0.183 & 0.033 & 5.517 & *** \\
\hline Water turbidity & -2.881 & 1.222 & -2.358 & * \\
\hline
\end{tabular}

Significance codes: ${ }^{* * *} \mathrm{p}<0.0001 ;{ }^{*} \mathrm{p}<0.01$.

winds - specially in northern steppe zone-would preclude the dispersal and colonization of Oc. albifasciatus. This would coincide with the lack of records in the northern steppe zone of the island.

In the present study, the vegetation was the predictor of Oc. albifasciatus. The abundance of immatures of this species was positively associated to gramineans. Many authors have reported that the presence of immatures of certain mosquito species is related to the presence of vegetation [e.g. 31-33]. Indirectly, the vegetation improves food supply, because the plants are providing suitable substrate for different types of microbiota [34]. Organic detritus is consumed by bacteria and fungi [35] as well as diverse macroinvertebrates including larval mosquitoes [36]. Field studies showed that a layer of leaves protected eggs of Oc. albifasciatus from extreme temperatures [37]. The grass, here, could play this function too. In addition, this organic detritus may alter the aquatic chemistry in water bodies, potentially influencing the attractiveness of these habitats to ovipositing female mosquitoes [38]. On the other hand, the presence of vegetation like grass could help the larvae to hide from potential predators by providing them shelter $[39,40]$. Therefore, the association of Oc. albifasciatus abundance with gramineans could be related with these aspects. In Argentina, this species was positively associated with grass in temporary pools in Buenos Aires City [27]. The macrophytes can also provide refuge and food for mosquitoes immature, however, these plants are more representative of habitats of more permanency of water. Oc. albifasciatus is a floodwater mosquito, because the females lay their eggs on the wet soil of habitats subject to cycles of drought and flood [7]. This would explain the lack of association between the abundance of this mosquito and macrophytes.

The negative association between abundance of inmatures of mosquitoes with water turbidity found in this study could be related to the presence of vegetation that favors retaining the substrate, reducing the dissolved solids in the water column, and thus reducing water turbidity.

\section{ACKNOWLEDGEMENTS}

We thank Thomas D. Goodall and his wife the biologist Rae Natalie Prosser Goodall, for their hospitality and for letting us stay overnight in Estancia Harberton during part of our fieldwork.

\section{REFERENCES}

[1] Forattini, O.P. (1998) Culicidae mosquitoes as emerging vectors of diseases. Revista de Saúde Pública, 32, 497502. http://dx.doi.org/10.1590/S0034-89101998000600001

[2] Burroni, N., Loetti, V., Freire, G., Marinone, C., Schweigmann, N. and Jensen, O. (2003) Characterization of larval habitat Ochlerotatus albifasciatus (Diptera: Culicidae) in Patagonia Argentina. Special Publication of Zoological Society of Uruguay, 1, 140.

[3] Burroni, N., Loetti, V., Freire, G., Jensen, O. and Schweigmann, N. (2007) New record and larval habitats of Culex eduardoi (Diptera: Culicidae) in an irrigated area of Patagonia, Chubut Province, Argentina. Memórias do Instituto Oswaldo Cruz, 102, 237-239. http://dx.doi.org/10.1590/S0074-02762007005000009

[4] Rossi, G.C. and Vezzani, D. (2011) An update of mosquitoes of Argentine Patagonia with new distribution records. Journal of the American Mosquito Control Association, 27, 93-98. http://dx.doi.org/10.2987/10-6082.1

[5] Bachmann, A.O. and Bejarano, J.E.R. (1960) Dispersion of mosquitoes in Patagonia (Culicidae Dipt.-Culicinae). Neotrópica, 6, 70-71.

[6] Marinone, M.C. (2002) New localities and observations on the presence of Ochlerotatus albifasciatus (Diptera: Culicidae) in Austral Patagonia. Publicación Especial Sociedad Entomológica Argentina, 2, 46-47.

[7] Forattini, O.P. (2002) Medical culicidology. Vol II. Identification, biology, epidemiology. Publisher of the University of São Paulo, São Paulo.

[8] Almeida, F.F and Gorla, D.E. (1995) Daily pattern of flight activity of Aedes albifasciatus in Central Argentina. Memórias do Instituto Oswaldo Cruz, 90, 638-644. http://dx.doi.org/10.1590/S0074-02761995000500020

[9] Horsfall, W.R. (1955) Mosquitoes: Their bionomics and relation to disease. The Royal Press Company, New York.

[10] Avilés, G., Bianchi, T.I. and Mitchell, C.J. (1990) Peroral susceptibility of Aedes albifasciatus and Culex pipiens complex mosquitoes (Diptera: Culicidae) from Argentina to Western Equine Encephalitis Virus. Revista de Saúde Pública, 24, 265-269. http://dx.doi.org/10.1590/S0034-89101990000400003

[11] Avilés, G., Sabattini, M.S. and Mitchell, C.J. (1992) Transmission of western equine encephalomyelitis virus by Argentine Aedes albifasciatus (Diptera: Culicidae). Journal of Medical Entomology, 29, 850-853.

[12] Sabattini, M.S., Avilés, G. and Monath, T.P. (1998) Historical, epidemiological and ecological aspects of arboviruses in Argentina: Flaviviridae, Bunyaviridae and Rhabdoviridae. In: Travassos da Rosa, A.P.A., Vasconcelos, P.F.C. and Travassos da Rosa, J.F.S., Eds., An Overview 
of Arbovirology in Brazil and Neighboring Countries, Instituto Evandro Chagas, Belém, 113-134.

[13] Sabattini, M.S., Avilés, G. and Monath, T.P. (1998) Historical, epidemiological and ecological aspects of Arboviruses in Argentina: Togaviridae, Alphavirus. In: Travassos da Rosa, A.P.A., Vasconcelos, P.F.C. and Travassos da Rosa, J.F.S., Eds., An Overview of Arbovirology in Brazil and Neighbouring Countries, Instituto Evandro Chagas, Belém, 135-153.

[14] Vezzani, D., Eiras, D.F. and Wisnivesky, C. (2006) Dirofilariasis in Argentina: Historical review and first report of Dirofilaria immitis in a natural mosquito population. Veterinary Parasitology, 136, 259-273.

http://dx.doi.org/10.1016/j.vetpar.2005.10.026

[15] Paruelo, J.M., Beltrán, A., Jobbágy, E., Sala, O.E. and Golluscio, R.A. (1999) The climate of Patagonia: General patterns and controls on biotic processes. Ecología Austral, 8, 85-101.

[16] Chiozza, E. and Figuera, R. (1982) Physical Atlas of Argentina. Vol 2. Total Atlas of Argentina. Publishing Center of Latin America Buenos Aires, Buenos Aires.

[17] Collantes, M.B. and Faggi, A.M. (1999) Wetlands of southern South America. In: Malvárez, I., Ed., Topics Subtropical and Temperate Wetlands of South America, MAB-UNESCO, Montevideo, 14-24.

[18] Cabrera, A.L. (1971) Phytogeography of Argentina. Boletín de la Sociedad Argentina de Botánica, 14, 1-43.

[19] Paruelo, J.M., Beltrán, A., Jobbágy, E., Sala, O.E. and Golluscio, R.A. (1998) The climate of Patagonia: General patterns and controls on biotic processes. Ecología Austral, 8, 85-101.

[20] O'Connor, A.S., Bradish, T., Reed, J., Moran, E., Regan, M., Visser, M., Gormally and Skeffington, M.S. (2004) A comparison of the efficacy of pond-net and box sampling methods in turloughs-Irish ephemeral aquatic systems. Hydrobiologia, 524, 133-144. http://dx.doi.org/10.1023/B:HYDR.0000036128.83998.4 4

[21] Braun-Blanquet, J. (1932) Plant sociology: The study of plant communities. MacGraw Hill, New York.

[22] Darsie Jr., R.F. (1985) Mosquitoes of Argentina. Part I. Keys for identification of adult females and fourth stage larvae in English and Spanish (Diptera, Culicidae). Mosquito Systematics, 17, 153-253.

[23] Reinert, J.F. (2001) Revised list of abbreviations for genera and subgenera of Culicidae (Diptera) and notes on generic and subgeneric changes. Journal of the American Mosquito Control Association, 17, 51-55.

[24] Crawley, M.J. (2007) The R Book. John Wiley and Sons, Ltd., West Sussex. http://dx.doi.org/10.1002/9780470515075

[25] Mitchell, C.J. and Darsie Jr., R.F. (1985) Mosquitoes of Argentina. Part. II. Geographic distribution and bibliography (Diptera, Culicidae). Mosquito Systematics, 17, 279-336.

[26] Almirón, W.R. (2002) Culicidae (Diptera) of the province of Córdoba. In: Salomón, O.D., Ed., Updates on Health Artropodología Argentina, Publicación Monográfica 2,
Buenos Aires, 97-113.

[27] Fischer, S., Marinone, C. and Schweigmann, N. (2002) Ochlerotatus albifasciatus in rain pools of Buenos Aires: Seasonal dynamics and to enviromental variables. Memórias do Instituto Oswaldo Cruz, 97, 767-773. http://dx.doi.org/10.1590/S0074-02762002000600002

[28] Fontanarrosa, M.S., Marinone, M.C., Fischer, S., Orellano, P.W. and Schweigmann, N. (2000) Effects of flooding and temperature on Aedes albifasciatus development time and larval density in two rain pools at Buenos Aires University City. Memórias do Instituto Oswaldo Cruz, 95, 787-793. http://dx.doi.org/10.1590/S0074-02762000000600007

[29] Campos, R.E., Fernández, L.A. and Sy, V.E. (2004) Study of the associated with the floodwater mosquito Ochlerotatus albifaciatus (Diptera: Culicidae) and their possible predators in Buenos Aires Province, Argentina. Hydrobiologia, 524, 91-102.

http://dx.doi.org/10.1023/B:HYDR.0000036122.10578.d $\underline{0}$

[30] Almirón, W.R. and Brewer, M.E. (1996) Classification of inmature stage habitats of Culicidae (Diptera) collected in Córdoba, Argentina. Memórias do Instituto Oswaldo Cruz, 91, 1-9. http://dx.doi.org/10.1590/S0074-02761996000100001

[31] Rejmankova, E., Savage, H., Rodriguez, M.H., Roberts, D.R. and Rejmanek, M. (1992) Aquatic vegetations basis for classification of Anopheles albimanus Weideman (Diptera: Culicidae) larval habitats. Environmental Entomology, 21, 598-603.

[32] Rodriguez, A.D., Rodriguez, M.H., Meza, R.A., Hernandez, J.E., Rejmankova, E., Savage, H.M., Roberts, D.R., Pope, K.O. and Legters, L. (1993) Dynamics of population densities and vegetation associations of Anopheles albimanus larvae in a coastal area of southern Chiapas, Mexico. Journal of the American Mosquito Control Association, 9, 46-58.

[33] Savage, H.M., Rejmankova, E., Arredondo-Jimenez, J.I., Roberts, D.R. and Rodríguez, M.H. (1990) Limnological and botanical characterizacion of larval habitats for two primary malarial vectors Anopheles albimanus and Anopheles pseudopunctipennis, in coastal areas of Chiapas state, Mexico. Journal of the American Mosquito Control Association, 6, 612-620.

[34] Cáceres, F. and Ruiz, S. (2004) Distribution of Ochlerotatus caspius (Pallas) and Oc. detritus (Haliday) (Diptera: Culicidae) oviposition in ecosystem of tidal flooding in Huelva. Boletín de Sanidad vegetal. Plagas, 30, 663670 .

[35] Kadlec, R.H. and Knight, R.L. (1996) Treatment wetlands. Lewis Publishers, Boca Raton.

[36] Fish, D. and Carpenter, S.R. (1982) Leaf litter and larval mosquito dynamics in tree-hole ecosystems. Ecology, 63, 283-288. http://dx.doi.org/10.2307/1938943

[37] Yanoviak, S.P. (1999) Effects of Mecistogaster spp. (Odonata: Pseudostigmatidae) and Culex mollis (Diptera: Culicidae) on litter decomposition in neotropical treehole microcosms. Florida Entomologist, 82, 462-468. http://dx.doi.org/10.2307/3496872 
[38] Campos, R.E and Sy, V.E. (2006) Variation in the hatching response of Ochlerotatus albifasciatus egg batches (Diptera: Culicidae) in temperate Argentina. Memórias do Instituto Oswaldo Cruz, 101, 47-53.

http://dx.doi.org/10.1590/S0074-02762006000100009

[39] Oyewole, I.O., Momoh, O.O., Anyasor, G.N., Ogunnowo, A.A., Ibidapo, C.A., Oduola, O.A., Obansa, J.B. and Awolola, T.S. (2009) Physico-chemical characteristics of Anopheles breeding sites: Impact on fecundity and progeny Development. African Journal of Environmental
Science and Technology, 3, 447-452.

[40] Sih, A. (1986) Antipredator responses and the perception of danger by mosquito larvae. Ecology, 67, 434-441. http://dx.doi.org/10.2307/1938587

[41] Tadesse, D., Mekonnen, Y. and Tsehaye, A. (2011) Characterization of mosquito breeding sites in and in the vicinity of Tigray microdams. Ethiopian Journal of Health Sciences, 21, 57-66. 